ppi $201502 Z U 4645$

Esta publicación científica en formato digital es continuidad de la revista impresa ISSN-Versión Impresa 0798-1406 / ISSN-Versión on line 2542-3185Depósito legal pp $197402 Z$ U34
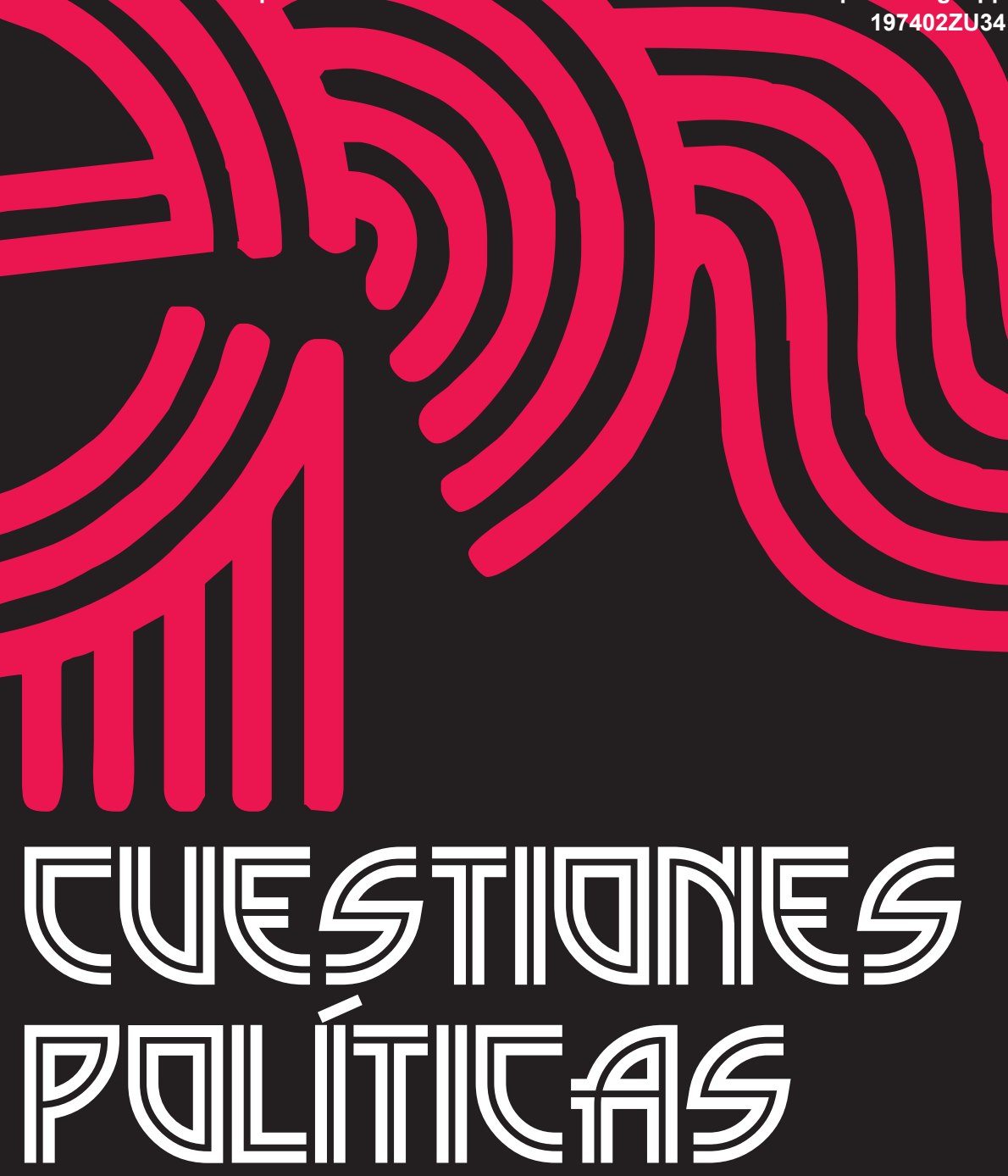

Instituto de Estudios Políticos y Derecho Público "Dr. Humberto J. La Roche" de la Facultad de Ciencias Jurídicas y Políticas de la Universidad del Zulia Maracaibo, Venezuela
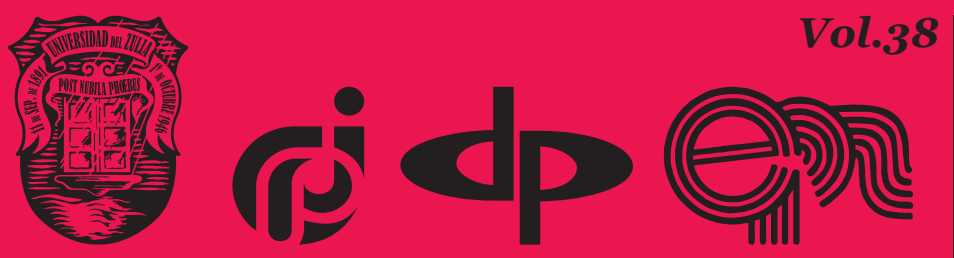

$N^{\circ}$ Especial 2da Parte 2020 


\title{
Identifying the Mental Model of the Managers of Melli Bank Regarding Quantum Leadership using Q-methodology
}

\author{
DOI: https://doi.org/10.46398/cuestpol.382e.o7
}

\author{
Ghasem Shariatikia * \\ Malikeh Beheshtifar ** \\ Mohammad Montazeri *** \\ Hossein Kazemi $* * * *$
}

\section{Abstract}

At Bank Melli Iran, which is the site of research, there are different opinions and views on quantum leadership, each of which is representing a specific intellectual model on the subject. These diverse opinions form a space for discourse. This study will identify this discursive space in detail and also analyze it in order to reveal organizational models to present strategies to plan the improvement of Bank Melli's policies and plans. The methodology used in this research is Q-sort or Q-methodology. This methodology was able to reveal several courses in the speech forum. Studying discursive space, 74 factors were detected. In analyzing these propositions, finally, 59 factors formalized Q expressions. These propositions that form the Q order, were written by paras on 59 cards. A sample of Bank Melli managers was then selected using Q-sort arrange for these cards on the Q-chart using defined instructions. In interpreting and the results obtained, three large models were identified including the ambassadors of change, the pioneers of protection and the drivers of stability.

Keywords: Melli Bank; leadership typology; intellectual model;; Q methodology;; quantum leadership.

\footnotetext{
* PhD Student, Department of Management, Rafsanjan Branch, Islamic Azad University, Rafsanjan, Iran. ORCID ID: https://orcid.org/oooo-0002-5981-1663. Email: Shariatikia1@gmail.com

** Associate Professor, Department of Management, Rafsanjan Branch, Islamic Azad University, Rafsanjan, Iran. ORCID ID: https://orcid.org/oooo-ooo2-2157-288X. Email: M.beheshtifar@yahoo. com

*** Assistant Professor, Department of Management, Payam Noor University, Tehran, Iran. ORCID ID: https://orcid.org/oooo-0002-8880-4219. Email: Montazer56@yahoo.com

****Assistant Professor, Management and economic Department, Vali-e-Asr University, Rafsanjan, Iran. ORCID ID: https://orcid.org/oooo-0oo3-4898-8946. Email: h.kazemi@vru.ac.ir
} 


\section{Identificación del modelo mental de los gerentes de Melli Bank en relación con el liderazgo cuántico utilizando la metodología Q}

\section{Resumen}

En Bank Melli Irán, que es el lugar de la investigación, hay diferentes opiniones y puntos de vista con respecto al liderazgo cuántico, cada uno de los cuales es representativo de un modelo intelectual específico con respecto a este tema. Estas diversas opiniones forman un espacio de discurso. Este estudio busca identificar en detalle este espacio discursivo y también analizarlo con el fin de revelar los modelos intelectuales de organización para presentar estrategias para planificar la mejora de las políticas y planes de Bank Melli. La metodología utilizada en esta investigación es Q-sort o Q-metodología. Esta metodología pudo revelar varias mentalidades en el foro del discurso. Estudiando el espacio discursivo, se detectaron 74 factores. Al analizar estas proposiciones, finalmente, 59 factores formaron expresiones Q. Estas proposiciones que forman el orden Q, se escribieron por separado en 59 tarjetas. Luego, se seleccionó una muestra de los gerentes de Bank Melli usando Q-sort para organizar estas tarjetas en el Q-chart usando instrucciones definidas. Al interpretar y discutir los resultados obtenidos, se identificaron tres grandes modelos, incluidos los embajadores del cambio, los pioneros de la protección y los pilotos de la estabilidad.

Palabras clave: Melli Bank; tipología de liderazgo; modelo intelectual; metodología Q; liderazgo cuántico.

\section{Introduction}

In the changing and complicated world of twenty-first century, traditional methods of management and organization management. The leaders and managers of current era need novel methods and skills so that they can direct organization in an effective fashion (Mollayinejad, 2016). Today, managers are aware of this matter that the only fixed element of the equations of the current period is 'change'. Many of leaders know that stability in organizations, is an old-fashioned idea, and conventional management skills do not solve new organizational problems (Dargahi, 2013). Considering that Bank Melli, today, is the largest bank in Middle East with a capital of about 100 billion Rials, and a total of 3271 branches at home, 13 active branches and 4 subsidiaries abroad, and 180 working bank counters, as well as about 40 thousand staff, and which continued to use all its power for the development of the country with great national and 
popular support, many transformations have taken place in the country's banking sector in recent years (Gobadi et al., 2019).

Actually, the highly competitive nature of service industry, and also the importance of cooperation and collaboration, learning and customer relationship in this industry requires more time and effort for leadership activities (Douglas and Fredendall, 2004, p. 395; Gupta et al., 2005, p. 391; Montes, Moreno, \& Morales, 2005, p. 1163; Politis, 2003, p. 185). The intensification of Competitions in twenty-first century, has led to rapid changes in environment, and the increased complexity of the environmental interactions of organizations' business, thus increasing uncertainty in the environment and proving the need for quantum view in organizational analysis including banks. Therefore, given the need for shifting strategy towards quantum organizations, analyzing these kinds of organizations and their intricate relationships and interactions, calls for a new kind of leadership strategy so that it can further organization goals, and maintain the competitive ability of organizations by establishing proper mechanisms (Tavakoli et al., 2017, p. 35).

In the Bank Melli Iran set-up, established for ninety years, the focus has been on conventional methods of management and leadership in a totally traditional way, independent of novel, modern, and dynamic practical trainings, and also no required mechanism has been predicted and established to encounter the current competitive and dynamic situation. It appears that the theory of quantum leadership can provide required mechanisms to pursue high aims of Bank Melli Iran considering its dynamism, discovering, creativity, and uncertainty, and also to include categories of trust, thinking together, organizational learning, and celebrating differences, in the corporate culture of Bank Melli Iran. Thus, according to what was said earlier, the aim of current research is to design the model of quantum leadership in Bank Melli Iran using interpretivestructural modelling. Considering the aim of the research, research questions which drive the research are:

1. How is, currently, the mental model of the managers of Bank Melli Iran?

2. What components is the mental model of the managers of Bank Melli Iran composed of in terms of quantum leadership?

\section{Literature Review}

Gaedamini Harouni et al (2018) explore the impact of quantum leadership on the commitment to change through the quality of perceived communications of change and through preparing for change. The results 
of the study indicated that quantum leadership has positive and significant effect on the commitment to change through preparing for change, but does not have an impact on the commitment to change through the quality of change, and also the direct influence on the commitment to change is barely significant. In their study, Tavakoli et al. (2017) examined the nature of quantum leadership as a new approach in the leadership of twenty-first century organizations.

The result of this study showed that quantum leaders employ six major strategies and actions including participatory decision-making, creating an atmosphere of trust and support for individuals, creating an interactive atmosphere and teamwork, facilitating information flow, encouraging self-organization and self-control, and supporting creativity and creating excitement. In his seminal paper entitled The Analysis of Quantum Learning in Optimizing the Learning of Human Resources, Mohammad Hadi (2017) focused on the application of quantum physics concepts in explaining practical and conceptual issues of the main core of this educational system, that is learning and teaching. The findings of this study highlighted that quantum approach is considered to be an effective method for optimizing the performance of educational systems in complex and obscure situations, and thus we can use this approach to improve the learning of human resources.

Based on the study conducted by Şenses \& Temoçin (2018), quantum leadership is focus on the world full of the qualities of quantum physics such as disorder, chaos, uncertainty, and indecision, and combined leadership focuses on those leaders who manage their organizations using common methods. At the end of the research, these leadership models, which are able to manage twenty-first century, are investigated using an interdisciplinary given their similarities and differences.

In their seminal text, The Analysis of Quantum View in School Leadership, Haris et al. (2016) reviewed the principles of effective leadership in changing school nature. This study indicated that even if approaching quantum leadership is not enough in a high education school, effective management through quantum skill is required for implementing is in a good school, especially in changing the nature of school management. Mundiri and Wijhi Ningtias (2015) conducted a research entitled The Role of Teacher's Quantum Leadership in Improving the Quality of Education on the Basis of Boarding University. According to the results of this study, quantum leadership can be conducive, effective and efficient as a leadership concept that can affect students in the learning process. 


\section{Theoretical groundings of the research}

\subsection{Quantum leadership}

Today, conventional beliefs regarding organizational environment are limited, influenced by mechanical thinking worldview. Environmental dynamics has led to the emergence of a new generation of organizations called 'quantum organization' (Agababayi et al., 2013). Effective leadership in quantum organization requires specific behaviors and skills that can be defined in the form of quantum leadership. Quantum leadership is a style of leadership where there is trust, security, dynamic interaction, and also learning among leaders and members, and where vertical interactions are decreased and horizontal interactions are increased (Deardorff and Williams, 2006).

Quantum leadership relies on non-hierarchical networks, influence is a function of individual characteristics, and there are extensive interactions between individuals in the group. Quantum leaders create a structure within the organization that eliminates the duality and conflict that has long existed in agencies and among the goals of individuals and groups, and helps individuals within the organization thrive as an individual in the creative team. A quantum leader gives out light and also the capabilities that s/he possesses, among organization's staff, and at the same time, is inspired by the group of employees under his or her supervision (Lazaridou \& Fris, 2006). In fact, quantum leadership is a style of leadership that is grounded on progress with the flow of organization, and also on the tendency towards self-organizing and working with ambiguity and uncertainty about future (Afjeh and Hamzehpour, 2015). In quantum approach, leaders need a new approach towards human being, processes, and objects to boost the effectiveness of performance. Quantum leadership shifts the view of leaders from top to bottom, and from the inside to the outside of organization.

\subsection{The psychology of quantum paradigm}

Psychologically speaking, quantum paradigm has a unique viewpoint. Contrasted with Newtonian paradigm that focuses on individualism and focusing on functional components, quantum paradigm is totalitarian and focuses on relations (Zohar, 1998).

In this view, nothing is static (Stacey et al., 2000). Nature continues to change where uncertainty dominates (Zohar, 1998). In quantum paradigm, nature is assumed to be complex, turbulent, and unpredictable in a way that it can hardly be controlled by the direct involvement of human being (Fris \& Lazaridou, 2006). 
According to these assumptions from the viewpoint of quantum paradigm in management, achieving knowledge through analyzing research propositions is not possible under precisely controlled conditions. In this paradigm, knowledge is acquired through presenting various interpretations of reality, and creating agreed-upon model. Based on quantum paradigm, due to the nature of the obscure and highly interactive boundaries of quantum phenomena called 'conceptualism', to understand, measure, and use the model, we must observe them in a larger conception which defines the relationships in those phenomena. Therefore, quantum approach puts and emphasis on qualitative research method to understand reality (Gummesson, 2006). One of the salient features of this type of research, is that it sees the world as composed of multiple realities and assumes a kind of mental relationship between researcher, and participants or subjects (Sarantakos, 1998).

\subsection{The dimensions of quantum leadership}

This type of leadership based on the best decision in complex situations, requires having seven quantum skills that enables the leaders of organizations to think dynamically and intuitively. In other words, leadership cannot be defined as influencing others to realize specific goals, but it should be defined as a process where searching goal and moving in its direction is more significant and valuable than the goal itself (Stumpf, 1995).

The macro-dimensions of quantum leadership are as follows:

1. Discovering: quantum leader asks followers to express their questions and problems, and the needs of people are identified though discourse about organization's tensions.

2. Authenticity: this trait makes the discovering trait more meaningful. Not until the leader earns the trust of followers, can s/ he discover their problems.

3. Full of excitement and passion: If human being does not have excitement and passion, there is no driving force for continuing life. Now, if the leader does not have this trait, how can s/he motivate his/her followers, help them overcome their fears, and have the initiative and power to transform?

4. Creating: We must always move in consort with world; We need novel ways of thinking, creating thoughts and new things in the future world. We “don't know what we don't know". If we can think, we can create (Guan McCaw). The creativity and knowledge of staff is vital for organizations' success. 
5. The builder of relationship: The relationship between human beings and managers has changed in quantum era. We must be aware that we can't live individually. Thus, we must learn how to interact and to bridge the cultural and language gap. quantum leadership focuses on the relationship and awareness of products, services, and processes.

6. Inquiry: Research is a tool for developing discovery paradigm. People must be awarded for their questions because they are the driving force for research and for discovering realities. They identify the future needs of the organization so that they can detect the kind of research for discovering and developing effective factors.

7. Fiscal astuteness: the core of quantum leadership is fiscal astuteness and accounting (Shelton \& Darling, 2001).

\section{Research methodology}

Regarding results, this study is primarily a developmental research, and secondarily a practical research. Also, regarding research aims, this study is primarily an exploratory research, and secondarily a descriptive research. Primarily, this study is qualitative research, and secondarily a quantitative research. In fact, we used mixed method in this study, a combination of quantitative and qualitative methods. In this research, we used Q-methodology. Therefore, considering the aim of research which is 'the typology of the mental model of the managers of Bank Melli with respect to quantum leadership using Q-sort', by conducting preliminary investigations, it was decided that thematic analysis be used to provide the ground for analyzing Q-methodology.

Thematic analysis is one of qualitative research methods. The managers of Melli Bank who have studied about leadership and have a long experience in senior management positions of bank Melli, and also have postgraduate education in management, have been selected as the statistical population of the research. In this research, a total of 12 samples were selected, and the sampling method was non-probability purposive sampling. The subjects selected were managers. Archive study was used to gather theoretical bases in this research, such as books and articles related to the topic, and the data were collected using interview. Of course, it should be noted that the interviews will continue as long as we are theoretically sure of the allinclusiveness of discourse space.

Regarding goals, this study is secondarily is an explanatory research, and regarding results, a practical research, and finally regarding data, quantitative research. Considering that in the first phase of the research 
using Q-methodology, the steps for identifying mental models have been taken, Q-methodology has been used in quantitative phase. In quantitative research, there is a population at the level of which the research results are applied, and includes a sample that was selected using random sampling and is generally the representative of that population. Q-methodology lacks such a populations and sample, and usually researcher selects people among those who either have specific relation with the research topic or have particular opinions. In this process, after selecting research topic, we, first, gathered whatever exists about that topic in various forms called 'concourse'. It should now be sorted out by evaluating and summarizing the contents of concourse.

For Instance, the texts of interviews, memoirs, articles, newspapers, etc. are converted into short and separate phrases so that, in the next step, a sample of phrases (i.e., Q-sample) can be selected from among them. Moreover, we can use the phrases prepared in previous researches for this purpose (Shinebourne, 2009). Each one of the phrases are written separately on one card to prepare Q-pack.

In the next stage, we select participants, i.e., those whose mentalities are supposed to be identified. Sorting constitutes the data collection stage where each participant sorts the Q-pack of cards according to specific instructions on a spectrum. The last stage is about analyzing collected data using factor analysis method and by interpreting extracted factors. The totality and appearance of the above process is very similar to making a scale like Likert scale. In Likert scale, also, researcher, primarily, collects a set of items, and then selects some that are more proper than others to make his/her scale. After finalizing the scale, a sample of subjects are selected using probability sampling, and the interview form is filled out by respondent. Finally, after entering questionnaire data into computer, data are processed and analyzed using statistical methods.

Generally speaking, various tools are used by researchers for collecting information. Field research and questionnaire were used in this research. In the previous section, the stages of studying Q-methodology were introduced until data collection was ended. Now, it is time to carry out a statistical analysis of that addresses the following questions:

1. What phrases did participants score in the same way?

2. In contrast, what phrases made a distinction between participants?

3. What different mindsets can we identify among participants?

Factor analysis, a multivariate method, is used to do a statistical analysis of the data derived from sortings. After finalizing sorting and before statistical analysis, data have to be entered into the computer so that dataset will be created for the statistical analysis by computer. To this end, it is 
necessary to record the sorting of each participant, because the movement of Q-chart, while the cards are on it, will cause them to disintegrate.

After finalizing factor analysis, i.e., the extraction and alternation of factors and achieving significant factor loadings and important factors, it is time for accurate interpretation of factors, which is determining meaning and their definition. The factor analysis of phrases (cards) creates a link between the content of phrases and factors, thus allowing the interpretation of factors.

\section{Research findings}

\subsection{Thematic analysis}

In this section, we will deal with studying the findings of thematic analysis, and will extract associated themes. Obviously, due to the different framework that is required by qualitative analyses in studies, the reporting method in these researches is very different from quantitative studies. The following is a brief reference the step-by-step expression of research process. As was noted in methodology section, thematic analysis is composed of six steps in terms of structure, but due to its reversibility, it is possible to return to previous step(s) repeatedly. Table 1 . shows initial concepts (themes) that researcher has identified.

Table 1. extracted themes

\begin{tabular}{|c|c|c|}
\hline Row & Descriptive codes & References \\
\hline 1 & $\begin{array}{c}\text { Human perceptions are highly } \\
\text { mental }\end{array}$ & $\begin{array}{c}\left\{\mathrm{M}_{2}, 7\right\} ;\left\{\mathrm{M}_{1}, 3\right\} ; \\
\left\{\mathrm{M}_{1}, 1\right\} ;\left\{\mathrm{M}_{9}, 3\right\}\end{array}$ \\
\hline 2 & $\begin{array}{c}\text { The talent of leading staff } \\
\text { should not be considered. The } \\
\text { procedure management itself } \\
\text { determines the selection of next } \\
\text { manager. }\end{array}$ & $\begin{array}{c}\left\{\mathrm{M}_{2}, 7\right\} ;\left\{\mathrm{M}_{12}, 7\right\} ; \\
\left\{\mathrm{M}_{5}, 1\right\}\end{array}$ \\
\hline 3 & $\begin{array}{c}\text { If there is collective decision- } \\
\text { making, there will be few } \\
\text { benefits for the organization. }\end{array}$ & $\begin{array}{c}\left\{\mathrm{M}_{12}, 4\right\} ;\left\{\mathrm{M}_{5}, 14\right\} ; \\
\left\{\mathrm{M}_{2}, 8\right\} ;\left\{\mathrm{M}_{2}, 1\right\}\end{array}$ \\
\hline 4 & $\begin{array}{c}\text { Doing things should focus } \\
\text { on interaction, cooperation, } \\
\text { equality, and relationship. }\end{array}$ & $\begin{array}{c}\left\{\mathrm{M}_{8}, 1\right\} ;\left\{\mathrm{M}_{7}, 1\right\} ; \\
\left\{\mathrm{M}_{5}, 1\right\} ;\left\{\mathrm{M}_{4}, 1\right\}\end{array}$ \\
\hline
\end{tabular}


Ghasem Shariatikia, Malikeh Beheshtifar, Mohammad Montazeri y Hossein Kazemi

Identifying the Mental Model of the Managers of Melli Bank Regarding Quantum Leadership

\begin{tabular}{|c|c|c|}
\hline 5 & $\begin{array}{l}\text { The work must be done in a } \\
\text { directional manner. }\end{array}$ & $\left\{\mathrm{M}_{7}, 29\right\} ;\left\{\mathrm{M}_{2}, 9\right\}$ \\
\hline 6 & $\begin{array}{l}\text { We need to look at events from a } \\
\text { different angle, because we may } \\
\text { understand new things. }\end{array}$ & $\begin{array}{l}\left\{\mathrm{M}_{2}, 4\right\} ;\left\{\mathrm{M}_{10}, 2\right\} \\
\left\{\mathrm{M}_{10}, 3\right\}\end{array}$ \\
\hline 7 & $\begin{array}{l}\text { Management in performing } \\
\text { duties, should focus on details } \\
\text { well. }\end{array}$ & $\begin{array}{l}\left\{\mathrm{M}_{7}, 19\right\} ;\left\{\mathrm{M}_{1}, 3\right\} \\
\left\{\mathrm{M}_{6}, 7\right\} ;\left\{\mathrm{M}_{2}, 12\right\} \\
\left\{\mathrm{M}_{3}, 3\right\} ;\left\{\mathrm{M}_{2}, 5\right\}\end{array}$ \\
\hline 8 & $\begin{array}{l}\text { Due to the complex nature } \\
\text { of factors, we must act with } \\
\text { great flexibility in addition to } \\
\text { observing fixed rules. }\end{array}$ & $\begin{array}{l}\left\{\mathrm{M}_{20}, 6\right\} ;\left\{\mathrm{M}_{3}, 13\right\} \\
\left\{\mathrm{M}_{20}, 17\right\} ;\left\{\mathrm{M}_{13}, 10\right\}\end{array}$ \\
\hline 9 & I believe in totalitarianism. & $\begin{array}{l}\left\{\mathrm{M}_{2}, 12\right\} ;\left\{\mathrm{M}_{2}, 7\right\} \\
\left\{\mathrm{M}_{8}, 7\right\} ;\left\{\mathrm{M}_{9}, 8\right\}\end{array}$ \\
\hline 10 & $\begin{array}{l}\text { Creating a procedure for doing } \\
\text { things is more important than } \\
\text { anything else. }\end{array}$ & $\begin{array}{l}\left\{\mathrm{M}_{5}, 7\right\} ;\left\{\mathrm{M}_{1}, 5\right\} \\
\quad\left\{\mathrm{M}_{10}, 14\right\}\end{array}$ \\
\hline 11 & $\begin{array}{l}\text { We need specific and pre- } \\
\text { determined principles to achieve } \\
\text { the goals of the bank. }\end{array}$ & $\left\{M_{12}, 4\right\} ;\left\{M_{7}, 33\right\}$ \\
\hline 12 & $\begin{array}{l}\text { To my opinion, applying } \\
\text { the current procedures of } \\
\text { organization, does not require } \\
\text { the use of creative thinking. }\end{array}$ & $\left\{M_{10}, 6\right\} ;\left\{M_{12}, 21\right\}$ \\
\hline 13 & & $\begin{array}{c}\left\{\mathrm{M}_{3}, 15\right\} ;\left\{\left\{_{\mathrm{M}_{2}}, 4\right\}\right. \\
\left\{\mathrm{M}_{2}, 7\right\}\end{array}$ \\
\hline 14 & $\begin{array}{l}\text { I believe that all parts of the } \\
\text { universe, including human being } \\
\text { and universe are dynamic, aware } \\
\text { and interrelated creatures. }\end{array}$ & $\begin{array}{l}\left\{M_{5}, 1\right\} ;\left\{M_{5}, 3\right\} \\
\left\{M_{2}, 6\right\} ;\left\{M_{9}, 13\right\}\end{array}$ \\
\hline 15 & $\begin{array}{c}\text { It would be better to be like a } \\
\text { trainer in performing duties } \\
\text { alongside staff. }\end{array}$ & $\begin{array}{c}\left\{\mathrm{M}_{2}, 2\right\} ;\left\{\mathrm{M}_{7}, 3\right\} \\
\left\{\mathrm{M}_{3}, 5\right\}\end{array}$ \\
\hline 16 & $\begin{array}{l}\text { The best method of doing things } \\
\text { is able to be conducted by } \\
\text { observing hierarchical structure. }\end{array}$ & $\begin{array}{l}\left.\mathrm{M}_{2}, 8\right\} ;\left\{\mathrm{M}_{2}, 2\right\} \\
\quad\left\{\mathrm{M}_{9}, 6\right\}\end{array}$ \\
\hline 17 & $\begin{array}{c}\text { Best type of banking staff are } \\
\text { those who carry out current } \\
\text { instructions. }\end{array}$ & $\left\{M_{6}, 9\right\} ;\left\{M_{6}, 4\right\}$ \\
\hline 18 & $\begin{array}{l}\text { Qualitative research method is } \\
\text { suitable to know reality. }\end{array}$ & $\left\{M_{7}, 15\right\} ;\left\{M_{26}, 2\right\}$ \\
\hline
\end{tabular}


CUESTIONES POLÍTICAS

Vol. $38 \mathrm{~N}^{\circ}$ Especial (2da parte 2020): 89-120

\begin{tabular}{|c|c|c|}
\hline 19 & $\begin{array}{l}\text { Being energetic in workplace } \\
\text { means working full-time. }\end{array}$ & $\begin{array}{c}\left\{\mathrm{M}_{3}, 10\right\} ;\left\{\mathrm{M}_{3}, 8\right\} \\
\left\{\mathrm{M}_{1}, 6\right\} ;\left\{\mathrm{M}_{6}, 3\right\}\end{array}$ \\
\hline 20 & $\begin{array}{l}\text { Decisions should be taken } \\
\text { individually. }\end{array}$ & $\begin{array}{c}\left\{\mathrm{M}_{2}, 18\right\} ;\{\mathrm{M} 10,6\} \\
\left\{\mathrm{M}_{8}, 2\right\} ;\left\{\mathrm{M}_{3}, 15\right\} \\
\left\{\mathrm{M}_{2}, 2\right\} ;\left\{\mathrm{M}_{9}, 1\right\}\end{array}$ \\
\hline 21 & $\begin{array}{l}\text { There is less commitment in } \\
\text { implementing group decisions. }\end{array}$ & $\left\{M_{7}, 27\right\} ;\left\{M_{1}, 3\right\}$ \\
\hline 22 & $\begin{array}{l}\text { Being in team contradicts the } \\
\text { concept of creativity. }\end{array}$ & $\begin{array}{c}\left\{\mathrm{M}_{8}, 8\right\} ;\left\{\mathrm{M}_{6}, 8\right\} \\
\left\{\mathrm{M}_{2}, 1\right\}\end{array}$ \\
\hline 23 & $\begin{array}{c}\text { Creativity has no application in } \\
\text { banking workplace. }\end{array}$ & $\left\{\mathrm{M}_{7}, 2\right\} ;\left\{\mathrm{M}_{8}, 12\right\}$ \\
\hline 24 & $\begin{array}{l}\text { Knowledge is gained } \\
\text { through presenting various } \\
\text { interpretations of reality, and } \\
\text { creating agreed-upon model. }\end{array}$ & $\left\{\mathrm{M}_{8}, 6\right\} ;\left\{\mathrm{M}_{10}, 4\right\}$ \\
\hline 25 & $\begin{array}{l}\text { In performance evaluation, we } \\
\text { must focus on the complexity of } \\
\text { situations and events. }\end{array}$ & $\left\{M_{7}, 13\right\} ;\left\{M_{11}, 8\right\}$ \\
\hline 26 & $\begin{array}{l}\text { People have to work individually } \\
\text { in performing duties. }\end{array}$ & $\left\{M_{3}, 4\right\} ;\left\{M_{4}, 5\right\}$ \\
\hline 27 & $\begin{array}{c}\text { We need to pay attention to the } \\
\text { context of events in analyzing } \\
\text { situations. }\end{array}$ & $\left\{M_{7}, 16\right\} ;\left\{M_{3}, 6\right\}$ \\
\hline 28 & $\begin{array}{l}\text { The mental nature of subjects } \\
\text { and examiner, also, needs to be } \\
\text { considered in analyzing events. }\end{array}$ & $\left\{M_{3}, 16\right\} ;\left\{M_{9}, 24\right\}$ \\
\hline 29 & $\begin{array}{l}\text { In the world, not only nothing } \\
\text { is predictable, but there is } \\
\text { no sufficient information for } \\
\text { understanding the situation. }\end{array}$ & $\begin{array}{l}\left\{\mathrm{M}_{3}, 3\right\} ;\left\{\mathrm{M}_{4}, 6\right\} \\
\quad\left\{\mathrm{M}_{10}, 12\right\}\end{array}$ \\
\hline 30 & $\begin{array}{l}\text { Achieving knowledge is not } \\
\text { possible by analyzing research } \\
\text { propositions under precisely } \\
\text { controlled conditions. }\end{array}$ & $\begin{array}{c}\left\{\mathrm{M}_{6}, 5\right\} ;\left\{\mathrm{M}_{2}, 3\right\} \\
\left\{\mathrm{M}_{1}, 12\right\} ;\left\{\mathrm{M}_{7}, 22\right\} \\
\left\{\mathrm{M}_{5}, 13\right\} ;\left\{\mathrm{M}_{2}, 3\right\}\end{array}$ \\
\hline 31 & $\begin{array}{l}\text { The world around us is based on } \\
\text { fixed laws that must be known. }\end{array}$ & $\left\{M_{7}, 21\right\} ;\left\{M_{8}, 4\right\}$ \\
\hline 32 & $\begin{array}{c}\text { Nature has a repetitive nature } \\
\text { that needs to be looked at merely } \\
\text { based on past thinking. }\end{array}$ & $\left\{M_{7}, 18\right\} ;\left\{M_{3}, 18\right\}$ \\
\hline 33 & $\begin{array}{l}\text { Nature laws can be understood, } \\
\text { predicted, and as a result, can be } \\
\text { controlled even on social topics. }\end{array}$ & $\left\{\mathrm{M}_{12}, 5\right\} ;\left\{\mathrm{M}_{4}, 5\right\}$ \\
\hline
\end{tabular}


Ghasem Shariatikia, Malikeh Beheshtifar, Mohammad Montazeri y Hossein Kazemi

Identifying the Mental Model of the Managers of Melli Bank Regarding Quantum Leadership

\begin{tabular}{|c|c|}
\hline $\begin{array}{c}\text { Work is in conflict with life } \\
\text { situation. }\end{array}$ & $\left\{\mathrm{M}_{7}, 3\right\} ;\left\{\mathrm{M}_{8}, 8\right\}$ \\
\hline $\begin{array}{c}\text { The function of each element } \\
\text { must be considered in its } \\
\text { analysis. }\end{array}$ & $\left\{\mathrm{M}_{8}, 3\right\} ;\left\{\mathrm{M}_{10}, 5\right\}$ \\
\hline
\end{tabular}

Competent staff are those who have enough motivation for performing their tasks.

The whole world is composed of energy that is reflected in every event and element.

The nature of life has stability that needs to be reflected in performing duties.

The nature of nature is

unpredictable, and is assumed

to be out the direct control of human being.

Managers must foster creativity
and innovation among their
staff.

Future managers are currently at organization, and they only need to be known.

Managers need a new approach towards human beings, processes, and objects to increase their performance effectivity.

Successful managers need those staff who are simply following instruction well.

$$
\left\{M_{6}, 14\right\} ;\left\{M_{7}, 4\right\}
$$

$\left\{M_{6}, 13\right\} ;\left\{M_{7}, 15\right\}$

(2)

$\left\{M_{7}, 9\right\} ;\left\{M_{7}, 24\right\}$

(1)

$\left\{\mathrm{M}_{10}, 11\right\} ;\left\{\mathrm{M}_{2}, 23\right\}$

y

$\left\{\mathrm{M}_{8}, 4\right\} ;\left\{\mathrm{M}_{7}, 11\right\} ;$
$\left\{\mathrm{M}_{6}, 3\right\} ;\left\{\mathrm{M}_{6}, 2\right\}$


CUESTIONES POLÍTICAS

Vol. $38 \mathrm{~N}^{\circ}$ Especial (2da parte 2020): 89-120

\begin{tabular}{|c|c|c|}
\hline 47 & $\begin{array}{l}\text { Management must be based on } \\
\text { rationality. }\end{array}$ & $\begin{array}{c}\left\{\mathrm{M}_{11}, 14\right\} ;\left\{\mathrm{M}_{3}, 16\right\} \\
\left\{\mathrm{M}_{2}, 20\right\} ;\left\{\mathrm{M}_{2}, 8\right\}\end{array}$ \\
\hline 48 & $\begin{array}{l}\text { Management means } \\
\text { superintending the performance } \\
\text { of tasks. }\end{array}$ & $\begin{array}{c}\left.\left\{\mathrm{M}_{7}, 11\right\} ;\left\{\mathrm{M}_{11}, 6\right\} ;\right\} ;\left\{\mathrm{M}_{6}, 40\right\} \\
\left\{\mathrm{M}_{6}, 31\right\}\end{array}$ \\
\hline 49 & $\begin{array}{l}\text { Traditional management is } \\
\text { also the best method to achieve } \\
\text { results in the current world. }\end{array}$ & $\left\{M_{5}, 11\right\} ;\left\{M_{9}, 16\right\} ;\left\{M_{3}, 14\right\} ;\left\{M_{7}, 13\right\}$ \\
\hline 50 & $\begin{array}{l}\text { The management of staff } \\
\text { depends on the participation of a } \\
\text { limited number of them. }\end{array}$ & $\left\{\mathrm{M}_{8}, 3\right\} ;\left\{\mathrm{M}_{9}, 26\right\}$ \\
\hline 51 & $\begin{array}{c}\text { Management means interaction } \\
\text { for the better performance of } \\
\text { duties. }\end{array}$ & $\begin{array}{l}\left\{\mathrm{M}_{2}, 5\right\} ;\left\{\mathrm{M}_{2}, 20\right\} \\
\left\{\mathrm{M}_{3}, 8\right\}\end{array}$ \\
\hline 52 & $\begin{array}{l}\text { Management means issuing } \\
\text { specific instructions for } \\
\text { performing tasks. }\end{array}$ & $\begin{array}{c}\left\{\mathrm{M}_{1} \mathrm{o}, 9\right\} ;\left\{\mathrm{M}_{3}, 11\right\} \\
\left\{\mathrm{M}_{9}, 9\right\} ;\left\{\mathrm{M}_{11}^{3}, 9\right\} \\
\left\{\mathrm{M}_{27}, 12\right\} ;\left\{\mathrm{M}_{9}, 4\right\} \\
\left\{\mathrm{M}_{8}, 5\right\} ;\left\{\mathrm{M}_{4}, 3\right\} \\
\left\{\mathrm{M}_{5}, 8\right\}\end{array}$ \\
\hline 53 & $\begin{array}{l}\text { Management depends on } \\
\text { creating the unity of procedure. }\end{array}$ & $\begin{array}{c}\left\{\mathrm{M}_{3}, 12\right\} ;\left\{_{\mathrm{M}_{4}}, 10\right\} \\
\left\{\mathrm{M}_{8}, 14\right\}\end{array}$ \\
\hline 54 & $\begin{array}{l}\text { We can consider conditions in } \\
\text { performing tasks, and can be } \\
\text { versatile. }\end{array}$ & $\left\{\mathrm{M}_{8}, 1\right\} ;\left\{\mathrm{M}_{6}, 7\right\}\left\{\mathrm{M}_{3}, 12\right\} ;\left\{\mathrm{M}_{7}, 10\right\}$ \\
\hline 55 & $\begin{array}{l}\text { We can provide dynamic } \\
\text { workplace for personnel to be } \\
\text { able to live in comfort. }\end{array}$ & $\left\{\mathrm{M}_{7}, 6\right\} ;\left\{\mathrm{M}_{3}, 11\right\} ;\left\{\mathrm{M}_{9}, 2\right\} ;\left\{\mathrm{M}_{12}, 8\right\}$ \\
\hline 56 & $\begin{array}{l}\text { Each organization is a small } \\
\text { world in terms of its complexity. }\end{array}$ & $\begin{array}{l}\left\{M_{11}, 3\right\} ;\left\{M_{3}, 2\right\} \\
\left\{M_{6}, 1\right\} ;\left\{M_{12}^{3}, 7\right\} \\
\left\{M_{11}, 5\right\}\end{array}$ \\
\hline 57 & $\begin{array}{l}\text { All of the events can be } \\
\text { interpreted individually, and } \\
\text { not everything should be seen in } \\
\text { relation to each other. }\end{array}$ & $\underset{\left.\left\{\mathrm{M}_{6}, 4\right\} ;\left\{\mathrm{M}_{6}, 21\right\} ;\right\} ;\left\{\mathrm{M}_{6}, 10\right\}}{\left\{\mathrm{M}_{6}, 11\right\}}$ \\
\hline 58 & $\begin{array}{l}\text { Everything can be interpreted } \\
\text { considering relations. }\end{array}$ & $\left\{\mathrm{M}_{3}, 2\right\} ;\left\{\mathrm{M}_{2}, 7\right\} ;\left\{\mathrm{M}_{3}, 11\right\}$ \\
\hline 59 & $\begin{array}{l}\text { A manager is successful only } \\
\text { when s/he provides his/her } \\
\text { staff with creative space and } \\
\text { environmental ambience. }\end{array}$ & $\begin{array}{l}\left\{\mathrm{M}_{6}, 5\right\} ;\left\{\mathrm{M}_{3}, 1\right\} \\
\left\{\mathrm{M}_{5}, 8\right\} ;\left\{\mathrm{M}_{11}, 2\right\} \\
\quad\left\{\mathrm{M}_{5}, 1\right\}\end{array}$ \\
\hline
\end{tabular}

Own elaboration basedon the objective of investigation. 
Ghasem Shariatikia, Malikeh Beheshtifar, Mohammad Montazeri y Hossein Kazemi

Identifying the Mental Model of the Managers of Melli Bank Regarding Quantum Leadership

\section{2. the descriptive analysis of research data}

The results of demographic indicated that out of 42 people, 14 percent of them, that is 6 people were females, and the rest, that is 86 percent of them, were males who were 36 people. Out of 42 subjects, 39, equivalent to 93 percent of them, were married and 3, only 7 percent of them, were single. Out of 42 subjects, 14 (33 percent) held bachelor's degree, 22 (52 percent) held master's degree, and 6 (14 percent) held doctoral degree. Out of 42 subjects, 5 , that is 12 percent of them, had working experience of between 5 to 10 years old; 11, that is 26 percent of them, had working experience of between 5 to 15 years old; and 26, that is 62 percent of them, had working experience of more than 15 years. Furthermore, the results of descriptive statistics including mean, standard deviation, and the number of observations were worked out for each one of variables.

\section{3. hypothesis testing}

The next step in carrying out factor analysis, is the sampling adequacy and analyzing the possibility of classifying data related to indices of measuring knowledge to a limited number of factors. Thus, sampling adequacy test (KMO index) as well as Bartlett's Test employed. The result of KMO test was equal to 0.64 which is greater than 0.6 (close to 1). Therefore, it could be concluded that the number of respondents was adequate for factor analysis, and the respective data can be reduced into underlying factors. Also, the results obtained from Bartlett's Test was found to be 59.419, suggesting that error less than 0.05 is acceptable at significant level. The possibility of symmetric error was found to be 0.000 , indicating the lack of multiplicity problem in the process of implementing factor analysis, and so factor analysis was evaluated to be proper for identifying structure.

Initial and extraction intersection test, have application to present initial intersection, special values, and the percentage of described variance. The intersection of a variable equals multivariate correlation raised to the power of $2\left(R^{2}\right)$ for relevant variable using factors as predictors. The results of this study showed that the extraction intersection of all factors was found to be 0.5, suggesting the desirable explanation of variables by extracted factors.

One of the basic issues in factor analysis is that each factor determines what percentage of the set of variables. Therefore, exploratory factor analysis was used for the main factor. The output of this part includes specific values, variance percentage, and the percentage of explained cumulative variance out of the set of variables through factors. 
In this study, since the number of input variables of factor analysis is 59 , initial 59 factors were formed, which 3 were left after extraction. Specific values shows variance percentage and cumulative percentage of variance for each one of factors, determining factors whose specific values are greater than 1 and remain in analysis. Factors whose value is less than 1 are excluded from the analysis or are placed in other groups. Factors excluded from factor analysis are those that will not lead to explaining variance. In this study, 3 factors remained in factor analysis.

Variance percentage is used to refer to the variance value that each factor could explain relative to the total variance of the set of variables. In this study, the first factor has the greatest variance of 45.467 , and as we move on to the next factors, its value decreases. The cumulative percentage of each factor equals the sum of the variance percentage of previous factors and the factor itself. In this study, the cumulative variance percentage for 3 factors was found to be 70.024, suggesting that 3 extracted factors cover just about 97 percent of the variance of the whole data, which is a good result.

\subsection{The map of Scree Plot}

Figure 1 shows the Scree Plot based on the considerable number of extracted factors as a chart. As can be seen from the Figure 1, the value of justified variance (specific value) includes four ruptures (in the second, sixth, thirteenth, and seventeenth factors), and after the fourth rupture, the specific value of factors has equal slope. Each one of these ruptures set the groundwork for indices grouping in factor analysis. Considering the cumulative variance percentage of initial specific values, second rupture (on third factor) was defined as s standard for grouping, because it covers 76.026 percent of the cumulative variance of data. After this factor, the cumulative variance percentage of specific variables, increases with very slight changes, and so the researcher identified 3 factors for grouping. 


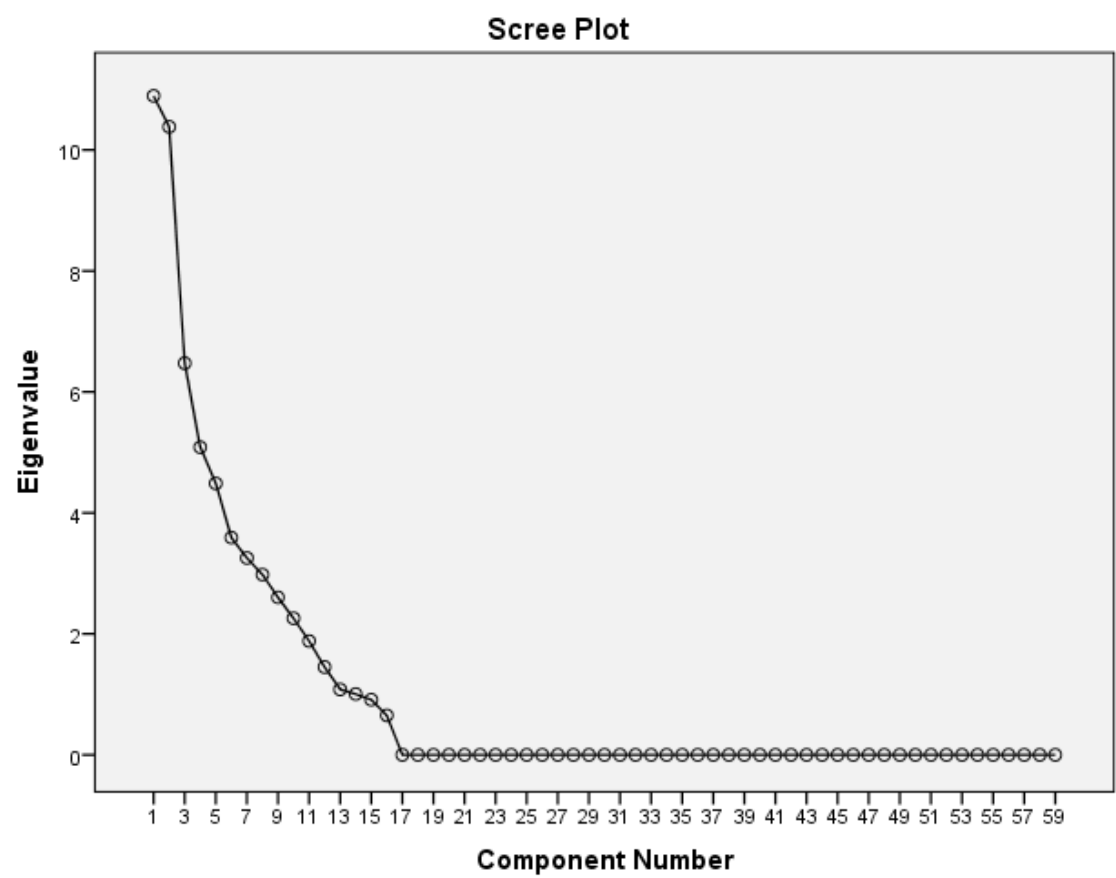

\section{Figure 1. Scree Plot. Own elaboration basedon the objective of investigation}

\subsection{Rotation matrix}

Researcher used SPSS software to perform this task and analyze data. In Table 2, rotation matrix has been shown. In this matrix, four available columns indicate extracted factor and before factor rotation, and rows also are representative of participants. As shown in table, factor loadings on each factor, have been sorted from the highest to the lowest, which leads to participants' classification based on Q-factor analysis. Accordingly, they have identified 22 propositions together in the first mental model, 23 in the second mental model, and 24 in the third mental model. Below the table, they also have referred to factor extraction method, factor rotation method, and the number of algorithm repetitions. 
Table 2. the rotation matrix of factor

\begin{tabular}{|c|c|c|c|}
\hline & \multicolumn{3}{|c|}{ Component } \\
\cline { 2 - 4 } & 1 & 2 & 3 \\
\hline Q09 & .902 & .240 & .308 \\
\hline Q15 & .847 & .006 & .064 \\
\hline Q51 & .847 & .176 & .197 \\
\hline Q55 & .841 & .220 & .461 \\
\hline Q59 & .788 & .094 & .237 \\
\hline Q01 & .743 & .145 & .166 \\
\hline Q28 & .712 & .084 & .082 \\
\hline Q39 & .703 & .095 & .183 \\
\hline Q14 & .694 & .073 & .320 \\
\hline Q56 & .688 & .059 & .088 \\
\hline Q04 & .671 & .230 & .265 \\
\hline Q07 & .662 & .185 & .134 \\
\hline Q18 & .658 & .029 & .132 \\
\hline Q58 & .651 & .023 & .211 \\
\hline Q24 & .629 & .070 & .128 \\
\hline Q44 & .623 & -.122 & -.093 \\
\hline Q57 & .569 & -.047 & .024 \\
\hline Q36 & .551 & -.122 & .078 \\
\hline Q40 & .541 & -.067 & .133 \\
\hline Q42 & .539 & -.165 & .135 \\
\hline Q37 & .525 & .254 & .147 \\
\hline Q29 & .508 & .249 & .351 \\
\hline Q27 & .14 & .841 & .148 \\
\hline Q32 & .236 & .814 & .226 \\
\hline Q38 & .093 & .774 & .127 \\
\hline Q03 & -.220 & .748 & .125 \\
\hline Q26 & .210 & .745 & .394 \\
\hline Q16 & .172 & .743 & .124 \\
\hline & & & \\
\hline & & .095 \\
\hline & .59 \\
\hline
\end{tabular}


Ghasem Shariatikia, Malikeh Beheshtifar, Mohammad Montazeri y Hossein Kazemi

Identifying the Mental Model of the Managers of Melli Bank Regarding Quantum Leadership 106 using Q-methodology

\begin{tabular}{|c|c|c|c|}
\hline Q19 & .423 & .714 & -.235 \\
\hline Qo8 & .254 & .694 & .051 \\
\hline Q45 & .279 & .688 & -.248 \\
\hline Q30 & .332 & .687 & $.47 /$ \\
\hline Qo6 & .110 & .671 & .112 \\
\hline Q54 & .223 & .669 & .238 \\
\hline Q17 & .145 & .668 & .412 \\
\hline Q22 & .320 & .662 & .258 \\
\hline Q12 & .215 & .612 & .358 \\
\hline Q34 & .278 & .608 & .347 \\
\hline Q25 & .361 & .558 & .314 \\
\hline Q46 & -.112 & .528 & .218 \\
\hline Q13 & .337 & .511 & .195 \\
\hline Q50 & .412 & .509 & .057 \\
\hline Q21 & .251 & .507 & .258 \\
\hline Q48 & .418 & .504 & .326 \\
\hline Q41 & .325 & .501 & .147 \\
\hline Q33 & .254 & .369 & .821 \\
\hline Q35 & .214 & .325 & .788 \\
\hline Q11 & .324 & .314 & .743 \\
\hline Q52 & .256 & .482 & .759 \\
\hline Q05 & .288 & .285 & .702 \\
\hline Q23 & .176 & .392 & .665 \\
\hline Q47 & .325 & .327 & .662 \\
\hline Q10 & .281 & .214 & .658 \\
\hline Q31 & .301 & .236 & .621 \\
\hline Q20 & .201 & .223 & .602 \\
\hline Q43 & .206 & .331 & .592 \\
\hline Q49 & .307 & .428 & .591 \\
\hline Q02 & .021 & .338 & .584 \\
\hline Q53 & .0281 & .210 & .559 \\
\hline
\end{tabular}

Own elaboration basedon the objective of investigation 


\subsection{Factor interpretation}

After finishing factor analysis, that is the extraction and rotation of factors and achieving significant factor loadings of significant factors, we move on to the full interpretation of factors, i.e., the meaning determination and their definition. The sorted phrases have been shown in Table 3, which given 59 available propositions, they have sorted from the highest to the lowest. Hence, the rank 59 is the highest rank, and 9 is the lowest rank, and the ranks between 1 to 8 represent indifference to the nature of job and the subject of their service.

\subsection{Identifying factor arrangements}

The factor arrangement I: considering the rotation matrix and the factor arrangements demonstrated in the form of Q-chart and Table 3, 22 propositions identify first mental model. They have identified factors 9,15 , 51,55 , and 59 as the most significant factors. This means that the abovementioned expressions represent the highest rank in terms of participants in first mental model. Also, they believe that factors 29, 37, and 42 have the least application. That is, these factors constitute the lowest rank.

Factor arrangement II: Further in the Table 3, it can be seen that 23 propositions that are common in the second mental model, have identified factors $27,32,38,3$, and 26 as the most important factors.

Factor arrangement III: Further in the Table 3, we see that 14 propositions being common in identifying third model, have identified factors $33,35,11,52$, and 5 as the most significant factors.

Table 3. ranking propositions for each factor

\begin{tabular}{|c|c|c|c|c|}
\hline Row & Proposition & $\begin{array}{c}\text { Factor } \\
\text { ranks of the } \\
\text { first mental } \\
\text { model }\end{array}$ & $\begin{array}{c}\text { Factor } \\
\text { ranks of } \\
\text { the second } \\
\text { mental } \\
\text { model }\end{array}$ & $\begin{array}{c}\text { Factor } \\
\text { ranks of } \\
\text { the third } \\
\text { mental } \\
\text { model }\end{array}$ \\
\hline 1 & $\begin{array}{c}\text { Human perceptions are } \\
\text { highly mental }\end{array}$ & 5 & 2 & 1 \\
\hline
\end{tabular}




\begin{tabular}{|c|c|c|c|c|}
\hline 2 & $\begin{array}{l}\text { The leading talents } \\
\text { of staff should not } \\
\text { be considered; the } \\
\text { procedure management } \\
\text { itself determines the } \\
\text { selection of the next } \\
\text { manager }\end{array}$ & 1 & 2 & 5 \\
\hline 3 & $\begin{array}{l}\text { If there is collective } \\
\text { decision-making, it will } \\
\text { have fewer benefits for } \\
\text { the organization }\end{array}$ & 1 & 8 & 2 \\
\hline 4 & $\begin{array}{l}\text { Performing duties should } \\
\text { focus on interaction, } \\
\text { cooperation, equality, } \\
\text { and relationship. }\end{array}$ & 6 & 1 & 1 \\
\hline 5 & $\begin{array}{l}\text { The work must be done } \\
\text { in a directional manner. }\end{array}$ & 1 & 2 & 7 \\
\hline 6 & $\begin{array}{c}\text { We need to look at } \\
\text { events from a different } \\
\text { angle, because we may } \\
\text { understand new things. }\end{array}$ & 1 & 5 & 1 \\
\hline 7 & $\begin{array}{c}\text { Management in } \\
\text { performing duties, } \\
\text { should focus on details } \\
\text { well. }\end{array}$ & 6 & 1 & 1 \\
\hline 8 & $\begin{array}{l}\text { Due to the complex } \\
\text { nature of factors, we } \\
\text { must act with great } \\
\text { flexibility in addition to } \\
\text { observing fixed rules. }\end{array}$ & 1 & 6 & 2 \\
\hline 9 & $\begin{array}{l}\text { I believe in } \\
\text { totalitarianism. }\end{array}$ & 8 & 1 & 1 \\
\hline 10 & $\begin{array}{l}\text { Creating a procedure } \\
\text { for doing things is more } \\
\text { important than anything } \\
\text { else. }\end{array}$ & 1 & 2 & 5 \\
\hline 11 & $\begin{array}{l}\text { We need specific } \\
\text { and pre-determined } \\
\text { principles to achieve the } \\
\text { goals of the bank. }\end{array}$ & 1 & 1 & 7 \\
\hline 12 & $\begin{array}{l}\text { To my opinion, applying } \\
\text { the current procedures } \\
\text { of organization, does } \\
\text { not require the use of } \\
\text { creative thinking. }\end{array}$ & 1 & 6 & 1 \\
\hline
\end{tabular}


CUESTIONES POLÍTICAS

Vol. $38 \mathrm{~N}^{\circ}$ Especial (2da parte 2020): 89-120

\begin{tabular}{|c|c|c|c|c|}
\hline 13 & $\begin{array}{c}\text { Budget needs to create } \\
\text { complete and predictable } \\
\text { procedures. }\end{array}$ & 1 & 5 & 2 \\
\hline 14 & $\begin{array}{l}\text { I believe that all parts of } \\
\text { the universe, including } \\
\text { human being and } \\
\text { universe are dynamic, } \\
\text { aware and interrelated } \\
\text { creatures. }\end{array}$ & 4 & 1 & 1 \\
\hline 15 & $\begin{array}{l}\text { It would be better to } \\
\text { be like a trainer in } \\
\text { performing duties } \\
\text { alongside staff. }\end{array}$ & 7 & 1 & 1 \\
\hline 16 & $\begin{array}{l}\text { The best method of } \\
\text { performing duties can be } \\
\text { conducted by observing } \\
\text { hierarchical structure. }\end{array}$ & 1 & 5 & 2 \\
\hline 17 & $\begin{array}{c}\text { Best type of banking staff } \\
\text { are those who carry out } \\
\text { current instructions. }\end{array}$ & 1 & 4 & 2 \\
\hline 18 & $\begin{array}{l}\text { Qualitative research } \\
\text { method is suitable to } \\
\text { know reality. }\end{array}$ & 4 & 2 & 2 \\
\hline 19 & $\begin{array}{l}\text { Being energetic in } \\
\text { workplace means } \\
\text { working full-time. }\end{array}$ & 2 & 5 & 2 \\
\hline 20 & $\begin{array}{l}\text { Decisions should be } \\
\text { taken individually. }\end{array}$ & 2 & 1 & 5 \\
\hline 21 & $\begin{array}{c}\text { There is less } \\
\text { commitment in } \\
\text { implementing group } \\
\text { decisions. }\end{array}$ & 2 & 5 & 2 \\
\hline 22 & $\begin{array}{l}\text { Being in team } \\
\text { contradicts the concept } \\
\text { of creativity. }\end{array}$ & 1 & 4 & 2 \\
\hline 23 & $\begin{array}{c}\text { Creativity has no } \\
\text { application in banking } \\
\text { workplace. }\end{array}$ & 2 & 2 & 5 \\
\hline 24 & $\begin{array}{l}\text { Knowledge is gained } \\
\text { through presenting } \\
\text { various interpretations } \\
\text { of reality, and creating } \\
\text { agreed-upon model. }\end{array}$ & 5 & 1 & 1 \\
\hline
\end{tabular}


Ghasem Shariatikia, Malikeh Beheshtifar, Mohammad Montazeri y Hossein Kazemi

Identifying the Mental Model of the Managers of Melli Bank Regarding Quantum Leadership 110 using Q-methodology

\begin{tabular}{|c|c|c|c|c|}
\hline 25 & $\begin{array}{l}\text { In performance } \\
\text { evaluation, also, we must } \\
\text { focus on the complexity } \\
\text { of situations and events. }\end{array}$ & 1 & 5 & 1 \\
\hline 26 & $\begin{array}{l}\text { People have to } \\
\text { work individually in } \\
\text { performing duties. }\end{array}$ & 1 & 7 & 2 \\
\hline 27 & $\begin{array}{l}\text { We need to pay attention } \\
\text { to the context of events } \\
\text { in analyzing situations. }\end{array}$ & 1 & 8 & 1 \\
\hline 28 & $\begin{array}{l}\text { The mental nature of } \\
\text { subjects and examiner, } \\
\text { also, needs to be } \\
\text { considered in analyzing } \\
\text { events. }\end{array}$ & 4 & 1 & 1 \\
\hline 29 & $\begin{array}{l}\text { In the world, not only } \\
\text { nothing is predictable, } \\
\text { but there is no } \\
\text { sufficient information } \\
\text { for understanding the } \\
\text { situation. }\end{array}$ & 4 & 1 & 2 \\
\hline 30 & $\begin{array}{l}\text { Achieving knowledge is } \\
\text { not possible by analyzing } \\
\text { research propositions } \\
\text { under precisely } \\
\text { controlled conditions. }\end{array}$ & 2 & 5 & 2 \\
\hline 31 & $\begin{array}{l}\text { The world around us is } \\
\text { based on fixed laws that } \\
\text { must be known. }\end{array}$ & 1 & 2 & 6 \\
\hline 32 & $\begin{array}{l}\text { Nature has a repetitive } \\
\text { nature that needs to be } \\
\text { looked at merely based } \\
\text { on past thinking. }\end{array}$ & 1 & 8 & 2 \\
\hline 33 & $\begin{array}{l}\text { Nature laws can be } \\
\text { understood, predicted, } \\
\text { and as a result, can be } \\
\text { controlled even on social } \\
\text { topics. }\end{array}$ & 1 & 1 & 8 \\
\hline 34 & $\begin{array}{l}\text { Work is in conflict with } \\
\text { life situation. }\end{array}$ & 1 & 4 & 1 \\
\hline 35 & $\begin{array}{l}\text { The function of } \\
\text { each element must } \\
\text { be considered in its } \\
\text { analysis. }\end{array}$ & 2 & 1 & 7 \\
\hline
\end{tabular}


CUESTIONES POLÍTICAS

Vol. $38 \mathrm{~N}^{\circ}$ Especial (2da parte 2020): 89-120

\begin{tabular}{|c|c|c|c|c|}
\hline 36 & $\begin{array}{l}\text { Competent staff } \\
\text { are those who have } \\
\text { enough motivation for } \\
\text { performing their tasks. }\end{array}$ & 5 & 1 & 1 \\
\hline 37 & $\begin{array}{l}\text { The whole world is } \\
\text { composed of energy that } \\
\text { is reflected in every event } \\
\text { and element. }\end{array}$ & 4 & 1 & 1 \\
\hline 38 & $\begin{array}{l}\text { The nature of life has } \\
\text { stability that needs to be } \\
\text { reflected in performing } \\
\text { duties. }\end{array}$ & 1 & 7 & 1 \\
\hline 39 & $\begin{array}{l}\text { The nature of nature is } \\
\text { unpredictable, and is } \\
\text { assumed to be out the } \\
\text { direct control of human } \\
\text { being. }\end{array}$ & 5 & 1 & 2 \\
\hline 40 & $\begin{array}{l}\text { Managers must foster } \\
\text { creativity and innovation } \\
\text { among their staff. }\end{array}$ & 4 & 1 & 1 \\
\hline 41 & $\begin{array}{l}\text { Future managers are } \\
\text { currently at organization, } \\
\text { and they only need to be } \\
\text { known. }\end{array}$ & 1 & 5 & 2 \\
\hline 42 & $\begin{array}{l}\text { Managers need a new } \\
\text { approach towards } \\
\text { human beings, } \\
\text { processes, and objects } \\
\text { to increase their } \\
\text { performance effectivity. }\end{array}$ & 4 & 2 & 1 \\
\hline 43 & $\begin{array}{l}\text { Successful managers } \\
\text { need those staff who } \\
\text { are simply following } \\
\text { instruction well. }\end{array}$ & 1 & 3 & 4 \\
\hline 44 & $\begin{array}{l}\text { Managers who perform } \\
\text { on the basis of quantum } \\
\text { theory, provide better } \\
\text { quality services } \\
\text { for customers and } \\
\text { stakeholders. }\end{array}$ & 4 & 1 & 1 \\
\hline 45 & $\begin{array}{l}\text { Managers must think } \\
\text { about the profit of } \\
\text { organization, and staff } \\
\text { need salaries. }\end{array}$ & 2 & 4 & 1 \\
\hline
\end{tabular}


Ghasem Shariatikia, Malikeh Beheshtifar, Mohammad Montazeri y Hossein Kazemi

Identifying the Mental Model of the Managers of Melli Bank Regarding Quantum Leadership

\begin{tabular}{|c|c|c|c|c|}
\hline 46 & $\begin{array}{l}\text { Managers must strive to } \\
\text { maintain their motivated } \\
\text { and creative staff in their } \\
\text { group. }\end{array}$ & 2 & 4 & 1 \\
\hline 47 & $\begin{array}{l}\text { Management must be } \\
\text { based on rationality. }\end{array}$ & 2 & 1 & 6 \\
\hline 48 & $\begin{array}{l}\text { Management means } \\
\text { superintending the } \\
\text { performance of tasks. }\end{array}$ & 1 & 5 & 2 \\
\hline 49 & $\begin{array}{l}\text { Traditional management } \\
\text { is also the best method } \\
\text { to achieve results in the } \\
\text { current world. }\end{array}$ & 1 & 1 & 4 \\
\hline 50 & $\begin{array}{c}\text { The management of } \\
\text { staff depends on the } \\
\text { participation of a limited } \\
\text { number of them. }\end{array}$ & 1 & 5 & 1 \\
\hline 51 & $\begin{array}{l}\text { Management means } \\
\text { interaction for the better } \\
\text { performance of duties. }\end{array}$ & 8 & 1 & 1 \\
\hline 52 & $\begin{array}{l}\text { Management means } \\
\text { issuing specific } \\
\text { instructions for } \\
\text { performing tasks. }\end{array}$ & 1 & 1 & 8 \\
\hline 53 & $\begin{array}{l}\text { Management depends } \\
\text { on creating the unity of } \\
\text { procedure. }\end{array}$ & 2 & 2 & 4 \\
\hline 54 & $\begin{array}{c}\text { We can consider } \\
\text { conditions in performing } \\
\text { tasks, and can be } \\
\text { versatile. }\end{array}$ & 1 & 3 & 1 \\
\hline 55 & $\begin{array}{l}\text { We can provide dynamic } \\
\text { workplace for personnel } \\
\text { to be able to live in } \\
\text { comfort. }\end{array}$ & 7 & 1 & 1 \\
\hline 56 & $\begin{array}{l}\text { Each organization is a } \\
\text { small world in terms of } \\
\text { its complexity. }\end{array}$ & 5 & 2 & 1 \\
\hline 57 & $\begin{array}{l}\text { All of the events can be } \\
\text { interpreted individually, } \\
\text { and not everything } \\
\text { should be seen in } \\
\text { relation to each other. }\end{array}$ & 4 & 2 & 1 \\
\hline
\end{tabular}




\begin{tabular}{|c|c|c|c|c|}
\hline 58 & $\begin{array}{c}\text { Everything can be } \\
\text { interpreted considering } \\
\text { relations. }\end{array}$ & 4 & 3 & 1 \\
\hline 59 & $\begin{array}{c}\text { A manager is successful } \\
\text { only when s/he } \\
\text { provides his/her staff } \\
\text { with creative space } \\
\text { and environmental } \\
\text { ambience. }\end{array}$ & 7 & 1 & 1 \\
\hline
\end{tabular}

Own elaboration basedon the objective of investigation.

After creating factor arrangements and displaying them as Q-spectrum, it is essential to analyze these models in detail based on factor arrangements for identifying distinguishing and agreement phrases and by means of which differences and similarities between mental models, so that distinguishing phrases, i.e., those that cause two factors to be considered separately, will be identified. In fact, such expressions give factor identity and determine its meaning and concept.

As an example, a proposition can earn scores of 1,8 , and 3 in factors 1,2 , and 3 , thus we see that this proposition is of significance for factor 2 , however, this is not the case for other factors. Therefore, this proposition distinguishes factor 2 from other factors. It is possible that a proposition plays a distinguishing role for two factors at the same time, but it may be important in one of them and insignificant in the other. To analyze mental models, in addition to distinguishing phrases, the phrases on the two sides of the spectrum, that is the highest and the lowest rank, are also applied, because they indicate opinions with great intensity. This is because, in this study, factor scores that are in the rows $8,7,1$, and 2 , are also identified.

\subsection{The typology of the mental model of the managers of Bank Melli regarding quantum leadership}

On the basis of propositions that have the highest or lowest score in each mental model and distinguishing propositions that have the highest and lowest significance in each model (these propositions have been highlighted), the mentality of the managers of Bank Melli was typified regarding quantum leadership. As shown in Table 4, this classification is described as follows: 


\section{Table 4. the typology of mentalities}

\begin{tabular}{|c|c|c|c|}
\hline $\begin{array}{l}\text { The priority } \\
\text { and the } \\
\text { score of } \\
\text { propositions }\end{array}$ & $\begin{array}{c}\text { Factor scores } \\
\text { of the first } \\
\text { menta model }\end{array}$ & $\begin{array}{l}\text { Factor scores of } \\
\text { the second menta } \\
\text { model }\end{array}$ & $\begin{array}{l}\text { Factor scores of } \\
\text { the third menta } \\
\text { model }\end{array}$ \\
\hline \multirow{3}{*}{8} & $\begin{array}{l}\text { I believe in } \\
\text { totalitarianism. }\end{array}$ & $\begin{array}{l}\text { If there is collective } \\
\text { decision-making, } \\
\text { there will be few } \\
\text { benefits for the } \\
\text { organization. }\end{array}$ & $\begin{array}{l}\text { Nature laws can } \\
\text { be understood, } \\
\text { predicted, and as } \\
\text { a result, can be } \\
\text { controlled even on } \\
\text { social topics. }\end{array}$ \\
\hline & $\begin{array}{l}\text { Management } \\
\text { means } \\
\text { interaction } \\
\text { for the better } \\
\text { performance of } \\
\text { duties. }\end{array}$ & $\begin{array}{l}\text { We need to pay } \\
\text { attention to the } \\
\text { context of events in } \\
\text { analyzing situations. }\end{array}$ & $\begin{array}{l}\text { Management } \\
\text { means issuing } \\
\text { specific instructions } \\
\text { for performing } \\
\text { tasks. }\end{array}$ \\
\hline & & $\begin{array}{l}\text { Nature has a } \\
\text { repetitive nature that } \\
\text { needs to be looked at } \\
\text { merely based on past } \\
\text { thinking. }\end{array}$ & \\
\hline \multirow[b]{2}{*}{7} & $\begin{array}{l}\text { We can provide } \\
\text { dynamic } \\
\text { workplace for } \\
\text { personnel to be } \\
\text { able to live in } \\
\text { comfort. }\end{array}$ & $\begin{array}{l}\text { People have to } \\
\text { work individually in } \\
\text { performing duties. }\end{array}$ & $\begin{array}{c}\text { The work must } \\
\text { be done in a } \\
\text { directional manner. }\end{array}$ \\
\hline & $\begin{array}{l}\text { A manager } \\
\text { is successful } \\
\text { only when s/ } \\
\text { he provides } \\
\text { his/her staff } \\
\text { with creative } \\
\text { space and } \\
\text { environmental } \\
\text { ambience. } \\
\end{array}$ & $\begin{array}{c}\text { The nature of life has } \\
\text { stability that needs } \\
\text { to be reflected in } \\
\text { performing duties. }\end{array}$ & $\begin{array}{l}\text { We need specific } \\
\text { and pre-determined } \\
\text { principles to } \\
\text { achieve the goals of } \\
\text { the bank. }\end{array}$ \\
\hline 2 & $\begin{array}{c}\text { Decisions } \\
\text { should be taken } \\
\text { individually. }\end{array}$ & $\begin{array}{c}\text { The talent of leading } \\
\text { staff should not } \\
\text { be considered. } \\
\text { The procedure } \\
\text { management itself } \\
\text { determines the } \\
\text { selection of next } \\
\text { manager. }\end{array}$ & $\begin{array}{l}\text { Future managers } \\
\text { are currently at } \\
\text { organization, and } \\
\text { they only need to } \\
\text { be known. }\end{array}$ \\
\hline
\end{tabular}




\begin{tabular}{|c|c|c|c|}
\hline $\begin{array}{c}\text { Creativity has } \\
\text { no application } \\
\text { in banking } \\
\text { workplace. }\end{array}$ & $\begin{array}{c}\text { Creating a procedure } \\
\text { for doing things is } \\
\text { more important than } \\
\text { anything else. } \\
\begin{array}{c}\text { There is less } \\
\text { commitment in } \\
\text { implementing } \\
\text { group decisions. }\end{array}\end{array}$ & $\begin{array}{c}\text { Management } \\
\text { means } \\
\text { superintending the } \\
\text { performance of } \\
\text { tasks. }\end{array}$ \\
\hline $\begin{array}{c}\text { Qualitative research } \\
\text { method is suitable to } \\
\text { know reality. } \\
\text { staff depends on } \\
\text { the participation } \\
\text { of a limited } \\
\text { number of them. }\end{array}$ & $\begin{array}{c}\text { The world around } \\
\text { us is based on fixed } \\
\text { laws that must be } \\
\text { known. }\end{array}$ \\
\cline { 2 - 4 } & $\begin{array}{c}\text { Knowledge is } \\
\text { presenting various } \\
\text { reality, and creating } \\
\text { agreed-upon model. }\end{array}$ & $\begin{array}{c}\text { I believe that } \\
\text { all parts of the } \\
\text { universe, including } \\
\text { human being } \\
\text { and universe are } \\
\text { dynamic, aware } \\
\text { and interrelated } \\
\text { creatures. }\end{array}$ \\
\hline $\begin{array}{c}\text { Work is in } \\
\text { conflict with life } \\
\text { situation. }\end{array}$ & $\begin{array}{c}\text { The mental nature } \\
\text { of subjects and } \\
\text { examiner, also, needs } \\
\text { to be considered in } \\
\text { analyzing events. }\end{array}$ & $\begin{array}{c}\text { Management in } \\
\text { performing duties, } \\
\text { should focus on } \\
\text { details well. }\end{array}$ \\
\hline
\end{tabular}

Own elaboration basedon the objective of investigation

\section{Discussion and conclusion}

This study attempts to typify the mental model of the managers of Bank Melli with regards to quantum leadership in addition to analyzing these models. Thus, author sought to select the sample Q-sort using thematic analysis and after studying concourse and summarizing the obtained propositions. The expressions of this sample were analyzed using Q-methodology, which was identified at the end of three mental models including the ambassadors of transformation, pioneers of protection, and the steersmen of stability, and of course this naming was done by the researcher.

\subsection{Initial mental type: the ambassadors of transformation}

This group has given most of its scores to propositions that have looked at leadership as strategies present in quantum leadership. They conceive of 
management as a cooperation mechanism, put value on staff, and expect that they can provide excellent services for their customer community using the creativity and innovation of their staff and due to their motivation and capabilities. They concentrate on interaction between working systems and staff, and view management as an interactive mechanism that is able to realize any goal using the capable hands of its employees.

Quantum leadership stresses interactive skills, dialogue, and trust in subordinates, and expects development and progress for both management and staff. In the analysis of Q-chart of these people, it can be seen that propositions like 'a manager is only successful when he can provide creative space and atmosphere' and 'it is better to be like a trainer in performing duties alongside staff', have the highest score and priority. By sharing leadership and management conditions with its employees in addition to listening to their voices, this group attempts to provide a dynamic and flexible working environment for its sub-groups, which both creates vitality and leads to intrinsic motivation in staff.

They ask followers to express their questions and problems, and so the needs of people are recognized through discourse about organizational tensions. They hold the view that there is no factor to continue life if there is no passion and excitement. Their orientation in the future world, is towards thinking about new ways of thinking, creating thoughts, and new things. The creativity and knowledge of staff is vital for the success of organizations. They acknowledge that we must be aware of the fact that we cannot live separately. So, we must learn how to interact and to close cultural and language gaps in our all-embracing communications.

\subsection{Second mental type: the pioneers of protection}

Those who fall into this group in the classification of this study, are those who continue management and inclination toward change after passing their dangerous career path. In this range of managers, there are those who tend to look at elaborate issues around them using quantum leadership style, but they are also afraid that they must fail by shifting from current procedures.

Although they believe in creativity, they consider themselves more as followers on this subject than to be the pioneers of this path and to take the risk. They apply smaller and slower changes in their services, compared with the managers of the ambassadors of transformation group, and are less likely to believe in stability and in defending past rules and protocols and unidimensionality. They struggle to attain limited and stable set of services, but follow carefully the selected set of new and upcoming transformations in similar activities. 
They are barely the first to act. In this study, the items of high priority in their descriptions in Q-samples include those like 'we need to pay attention to the context of events in analyzing situations' and 'nature has a repetitive nature that needs to be looked at merely based on past thinking'. They, somehow, follow quantum leadership approach in some of their thinking, and in their ideas and roots of thought, they, somehow, have a brief look at the rationalist style of the steersmen of stability. They are thinking and acting somewhere between continuing past rules and creating new future. It is apparent that such approaches prepare the ground for gradual change towards continuing quantum leadership.

\subsection{Third mental type: the steersmen of stability}

In the third mental type, we witness managers who introduce themselves as the forerunners of continuing past, and tend to move towards continuing past by creating defined procedures and instructions. Meanwhile, the managers believe that their employees should not have creativity, and, generally, there is no need for innovative thinking in performing their duties.

In fact, organization needs empowered officials who contribute to the organization in achieving goals by observing pre-determined instructions. In this regard, it could be argued that this group of managers strongly believe in Newtonian leadership thoughts, and consider it indispensable for development. They don't trust in their juniors, and change them to yesmans who are afraid of punishment.

In this management system and mental approach, managers have a tendency towards unidimensionality, and believe in unity of procedure in affairs. Reflecting on their intended items, we can see that the following cases have high mental priority among them: "Nature laws can be understood, predicted, and as a result, can be controlled even on social topics' and 'The function of each element must be considered in its analysis'. Legalism, focus on authority and the formalization of organizational structure, restrictions on the formation of work teams, and management base on seniority are among the mental models prevailing in the range of managers, and their success can be seen to a large extent as a style governing most of traditional businesses by reviewing the needs of current organizations. 
Ghasem Shariatikia, Malikeh Beheshtifar, Mohammad Montazeri y Hossein Kazemi

Identifying the Mental Model of the Managers of Melli Bank Regarding Quantum Leadership 118 using Q-methodology

\section{Bibliographic References}

AFJEH, Saa; HAMZEHPOUR, Michea. 2014. "A Comprehensive Approach to Quantum Leadership Theory and its Applications in the Organization" In: Strategic Management Thought. Vol. 8, No. 2, pp. 161-204.

AGABABYI, Raziye; HOVEYDA, Reza; RAJAYIPOUR, Saeid. 2013. "The Relationship between Positivist Leadership Strategies and the Components of Quantum Organization" In: Education Strategies in Medical Science. Vol. 6, No. 3, pp. 200-208.

AZIMI SANAVI, Babak; RAZAVI, Seyed Mohammad Hosein. 2014. "The Relationship between the Level of Familiarity and the Use of Quantum Skills of Management in Sports Organizations" In: The Journal of Sports Management. Vol. 6, No. 4, pp. 613-625.

SHELTON, Charlotte K; DARLING, Lohn R. 2001. "The quantum skills model in management: a new paradigm to enhance effective leadership" In: Leadership \& organization development journal. Vol. 22, No. 6, pp. 264273 .

DARGAHI, Helen, 2013. "Quantum Leadership, The Implication for Iranian Nursing Leaders” In: Acta Madica Iranica. Vol. 51, No. 6, pp. 411-417.

DEARDORFF, Dale S; WILLIAMS, Greg. 2006. "Synergy leadership in quantum organization" Available online. Is: https://citeseerx.ist.psu. edu/viewdoc/download?doi=10.1.1.476.7750\&rep=rep1\&type=pdf. Date of consulting: 12/03/2019.

DOUGLAS, Thomas J; FREDENDALL, Lawrence D. 2008. “The evolving theory of quality management: The role of Six Sigma" In: Journal of Operations Management. Vol. 26, No. 5, pp. 630-650.

FARIBORZ, Mohammad Hadi. 2011. "Quantum Paradigm in Management Science” In: Organizational Culture Management Quarterly. Vol. 9, No. 23, pp. 71-94.

FRIS, Joe; LAZARIDOU, Angeliki. 2006. "An Additional Way of Thinking About Organizational Life and Leadership: The Quantum Perspective" In: Canadian Journal of Educational Administration and Policy. Vol. 48, No. 5, pp. 1-29.

GANBARI, Sirous; MORADI, Ali. 2014. "The Relationship between Quantum Skills of Managers and Employee's Readiness for Organizational Change" In: Sports Leadership and Management Quarterly. Vol. 22, No. 3, pp. 87-109. 
GHAED AMINI HAROUNI, Abbas; EBRAHIMZADEH DASTJERDI, Reza; SADEGHI DEH CHESHMEH, Mehrdad; SADEGHZADEH, Nazanin. 2018. "The Impact of Quantum Leadership on Commitment to Change through the Quality of Communication Perceived of Change and Readiness for Change" In: Leadership and Management Research Educational. Vol 4, No. 15, pp. 152-176.

GHOBADI, Majid; ZOLFAGHARI ZAFARANI, Rashid; KALANTARI, Mehdi. 2019. "Presenting a Perceptual Framework for Institutionalizing the Competence of Managers in Bank Melli Iran" In: A New Approach in Educational Management, Vol. 37; No.1, pp. 74-88.

GUMMESSON, Evert. 2006. "Qualitative research in management: addressing complexity, context and persona” In: Management Decision. Vol. 44, No. 2, pp. 167-179.

GUPTA, Atul; MCDANIEL, Jason C; HERATH, Kanthi. 2005. "Quality management in service firms: sustaining structures of total quality service" In: Managing Service Quality: An International Journal. Vol. 15, No. 4, pp. 389-402.

HARIS, Ikhfan, A; AFDALIAH, Andi Budiman; HARIS, Khairul. 2016. "Exploring Quantum perspective in School Leadership: A Review of Effective Principal Leadership in the Changing Nature of School Management" In: International Journal of Social Sciences \& Educational Studies ISSN 2409-1294 (Print). Vol. 2, No. 4, pp. 112-123.

LAZARIDOU, Angeliki; FRIS, Joe. 2006. "An Additional Way of Thinking About Organizational Life and Leadership: The Quantum Perspective" In: Canadian Journal of Educational Administration and Policy. Vol. 48, No. 5, pp. 1-29.

MANOUCHEHRI, Hooman; SHAHAB LAVASANI, Fariba; ATASHZADEH SHOURIDEH, Foroozan; AKBARZADEH BAGHBAN, Ali Reza. 2017. "The Relationship between Leadership Style and Perceived Organizational Justice among Nurses" In: Nursing Management Quarterly. Vol. 6, No. 1, pp. 62-71.

MOKHTARI NOURI, Jamileh; KHADEM AL-HOSSEINI, Mojtaba. 2008. “The Application of Quantum Model in Nursing Leadership" In: Advances in Nursing and Midwifery. Vol. 18, No. 61, pp. 55-63.

MOLLAYINEJAD, Azam. 2016. "School and Quantum Leadership" In: The Journal of School Management. Vol. 14, No. 3, pp. 50-55.

MONTES, Fracisco Javier Lloréns; MORENO, Alexandra; MORALES, Victor Garcia. 2005. Influence of support leadership and teamwork cohesion on organizational learning, innovation and performance: an empirical 
Ghasem Shariatikia, Malikeh Beheshtifar, Mohammad Montazeri y Hossein Kazemi

Identifying the Mental Model of the Managers of Melli Bank Regarding Quantum Leadership

120 using Q-methodology

examination. Available online. In: https://www.infona.pl/resource/ bwmeta1.element.elsevier-c4e1d20c-b414-3b2e-8d65-c604756ab24d. Consultation date: 14/11/2019.

MUNDIRI, Akmal; WIJHI NINGTIAS, Renita. 2015. "Quantum Leadership Of Teachers In Improving The Quality Of Education Based On Pesantren” In: Journal Pendidikan Islam. Vol. 7, No. 1, pp. 01-33.

ŞENSES, Berrin; TEMOÇIN, Pınar. 2016. An Interdisciplinary Study: Quantum Leadership and Hybrid Leadership, International Symposium on Chaos. Complexity and Leadership, ICCLS 2016: Chaos, Complexity and Leadership, pp. 547-559.

SHELTON, Charlotte K; DARLING, John R. 1999. "The quantum skills model in management: a new paradigm to enhance effective leadership" Leadership \& Organization Development Journal. Vol. 22, No. 6, pp. 264-273.

SHINEBOURNE, Pnina; ADAMS, Martin. 2007. "Q-Methodology as a Phenomenological” In: Research Method. Vol. 8, No. 1, pp. 93-97.

STACEY, Ralph D; GRIFFIN, Douglas; SHAW, Patricia. 2000. Complexity \& Management: Fad or radical challenge to systems thinking?. UK, Rutledge, London.

STUMPF, Stephen A. 1995. "Applying new science theories in leadership development activities" In: Journal of Management Development. Vol. 14, No. 5, pp. 39-49.

TAVAKOLI, Abbas; MOHAMMADI, Ali; KHODAEI, Amin. 2017. "Kontomi leadership why what and how" In: Quarterly Journal of Organizational Behavior Studies. Vol. 6, No. 1) (Serial No. 21), pp. 33-56.

VAN EXEL, Job; DE GRAAF, Gjalt. 2005. Q methodology: A sneak preview. Available online. In: https://www.researchgate.net/ publication/228574836_Q_Methodology_A_Sneak_Preview. Consultation date: $28 / 04 / 2019$.

WALUMBWA, Fred O; LAWLER, John J; AVOLIO, Bruce J. 2007. “Leadership, Individual Differences, and Work related Attitudes: A Cross Culture Investigation" In: Applied Psychology. No. 56, pp. 212-230.

YAZDANI NESHAT, Arazm. 2010. Designing Work Motivation of the Staff of Iranian Offshore Oil Company (Unpublished master's thesis). The Faculty of Management and Accounting, Payame Noor University. Teheran, Iran.

ZOHAR, Dov. 1998. "Changing the thinking behind our thinking” In: Journal of Management Review. Vol. 87, No. 3, pp. 56-58. 
Vol.38 NEspecial

Esta revista fue editada en formato digital y publicada en diciembre de 2020, por el Fondo Editorial Serbiluz, Universidad del Zulia. Maracaibo-Venezuela 